\title{
Developmental neurotoxicity: the case of perfluoroalkylated compounds
}

\author{
C. Van Thriel · J. D. Stewart
}

Published online: 15 August 2012

(C) Springer-Verlag 2012

Due to the extremely high strength of the carbon-fluoride bond, perfluoroalkylated compounds tend to bioaccumulate in organisms. The knowledge concerning toxicity of PFCs, however, is limited. The nervous system appears to be particularly susceptible, especially when exposure occurs during development. In this issue of the Archives of Toxicology, Espen Mariussen gives a comprehensive review on mechanisms of action and environmental relevance of perfluoroalkylated compounds (Mariussen 2012; this issue). The author gives an overview of the available animal studies that suggest perfluoroalkylated compounds may cause neurobehavioral effects. There is only limited knowledge regarding the responsible mechanisms. In this context, it seems to be relevant that perfluoroalkylated compounds affect protein kinase $\mathrm{C}$ signalling that is known as a key factor of cell migration (Stewart et al. 2012), a process of particular relevance during the development of the nervous system.

Neurotoxicity (Takahashi et al. 2011; Nakamura et al. 2011; Li et al. 2011; Sriram et al. 2010; Liu et al. 2010) as well as developmental neurotoxicity (Pamies et al. 2010; Frimat et al. 2010; Hardelauf et al. 2011; Kadereit et al. 2012; Kuegler et al. 2010; Hartung et al. 2011) represent cutting-edge topics in toxicology, reflected by the particularly high number of articles in this field. However, little has been published discussing the neurotoxicity of perfluoroalkylated compounds, although they are still widely

C. Van Thriel $(\varangle)$ J J. D. Stewart

Leibniz Research Centre for Working Environment and Human

Factors (IfADo), Leibniz Institut für Arbeitsforschung an der TU Dortmund, Ardeystrasse 67, 44139 Dortmund, Germany

e-mail: thriel@ifado.de

J. D. Stewart

e-mail: J.D.Stewart@ soton.ac.uk used in pesticides, paints, clothes treatment, fire-fighting foams, carpets and leather products. The editors are pleased that Espen Mariussen will, therefore, address this topic with a particular focus on PFC concentrations in humans and animals, neurobehavioral studies and mechanisms of action. The review is highly recommended to anyone interested in developmental neurotoxicity.

\section{References}

Frimat JP, Sisnaiske J, Subbiah S, Menne H, Godoy P, Lampen P, Leist M, Franzke J, Hengstler JG, van Thriel C, West J (2010) The network formation assay: a spatially standardized neurite outgrowth analytical display for neurotoxicity screening. Lab Chip 10(6):701-709

Hardelauf H, Sisnaiske J, Taghipour-Anvari AA, Jacob P, Drabiniok E, Marggraf U, Frimat JP, Hengstler JG, Neyer A, van Thriel C, West J (2011) High fidelity neuronal networks formed by plasma masking with a bilayer membrane: analysis of neurodegenerative and neuroprotective processes. Lab Chip 11(16):2763-2771

Hartung T, Blaauboer BJ, Bosgra S, Carney E, Coenen J, Conolly RB, Corsini E, Green S, Faustman EM, Gaspari A, Hayashi M, Wallace Hayes A, Hengstler JG, Knudsen LE, Knudsen TB, McKim JM, Pfaller W, Roggen EL (2011) An expert consortium review of the EC-commissioned report "alternative (non-animal) methods for cosmetics testing: current status and future prospects-2010". ALTEX 28(3):183-209

Kadereit S, Zimmer B, van Thriel C, Hengstler JG, Leist M (2012) Compound selection for in vitro modeling of developmental neurotoxicity. Front Biosci 17:2442-2460

Kuegler PB, Zimmer B, Waldmann T, Baudis B, Ilmjärv S, Hescheler J, Gaughwin P, Brundin P, Mundy W, Bal-Price AK, Schrattenholz A, Krause KH, van Thriel C, Rao MS, Kadereit S, Leist M (2010) Markers of murine embryonic and neural stem cells, neurons and astrocytes: reference points for developmental neurotoxicity testing. ALTEX 27(1):17-42

Li H, Wu S, Shi N, Lin W, You J, Zhou W (2011) NF-E2-related factor 2 activation in PC12 cells: its protective role in manganese-induced damage. Arch Toxicol 85(8):901-910 
Liu X, Liu W, Jin Y, Yu W, Liu L, Yu H (2010) Effects of subchronic perfluorooctane sulfonate exposure of rats on calcium-dependent signaling molecules in the brain tissue. Arch Toxicol 84(6):471-479

Mariussen E (2012) Neurotoxic effects of perfluoroalkylated compounds: mechanisms of action and environmental relevance. Arch Toxicol. (this issue). doi:10.1007/s00204-012-0822-6

Nakamura M, Yasutake A, Fujimura M, Hachiya N, Marumoto M (2011) Effect of methylmercury administration on choroid plexus function in rats. Arch Toxicol 85(8):911-918

Pamies D, Reig JA, Vilanova E, Sogorb MA (2010) Expression of neuropathy target esterase in mouse embryonic stem cells during differentiation. Arch Toxicol 84(6):481-491

Sriram K, Lin GX, Jefferson AM, Roberts JR, Chapman RS, Chen BT, Soukup JM, Ghio AJ, Antonini JM (2010) Dopaminergic neurotoxicity following pulmonary exposure to manganesecontaining welding fumes. Arch Toxicol 84(7):521-540

Stewart JD, Marchan R, Lesjak MS, Lambert J, Hergenroeder R, Ellis JK, Lau CH, Keun HC, Schmitz G, Schiller J, Eibisch M, Hedberg C, Waldmann H, Lausch E, Tanner B, Sehouli J, Sagemueller J, Staude H, Steiner E, Hengstler JG (2012) Choline-releasing glycerol phosphodiesterase EDI3 drives tumor cell migration and metastasis. Proc Natl Acad Sci USA 109(21):8155-8160

Takahashi M, Inoue K, Koyama N, Yoshida M, Irie K, Morikawa T, Shibutani M, Honma M, Nishikawa A (2011) Life stage-related differences in susceptibility to acrylamide-induced neural and testicular toxicity. Arch Toxicol 85(9):1109-1120 